\title{
Benign Childhood Supratentorial Neoplasm
}

National Cancer Institute

\section{Source}

National Cancer Institute. Benign Childhood Supratentorial Neoplasm. NCI Thesaurus. Code C5799.

A non-metastasizing neoplasm that arises from the supratentorial region of the brain during childhood. 